\title{
The Impact of Deduako Community on Giving in the Church: A Mathematical Analysis
}

\author{
C. Nyarko Andam ${ }^{1}$ and W. Obeng-Denteh ${ }^{2}$ \\ ${ }^{1}$ Wesley Cathedral, Methodist Church Adum, Kumasi, Ghana. Email:andamcn@gmail.com \\ ${ }^{2}$ College of Science, Department of Mathematics, Kwame Nkrumah University of Science and \\ Technology, Kumasi, Ghana. Email: obengdentehw@yahoo.com
}

\begin{abstract}
The purpose of the study was to analyze "giving" among the members of the Deduako-Kodiekrom Society of the Methodist Church using mathematical tools in the analysis.Deduako-Kodiekrom is a community in the Ashanti Region of Ghana and is well endowed. Farming is part of the life of the people of the community and an appreciable number of them are teachers, doctors, businessmen and woman, lawyers, pastors, traders and a host of others. The analysis was based on data obtained from the church being the amounts given by members of the church in the last five Appeal-for-Funds held by the Church in the Church. Upon analysis, it was found out that there is a high level of giving in the church. At any of the appeal-for-funds held, the average amount given by each individual in the Church ranges between $7.10 \mathrm{GHC}$ and $10.80 \mathrm{GHC}$ which is good. The people are really generous in terms of giving to the Church in the Community. The study contributes to the literature by providing data-based evidence documenting the extent to which the importance of giving held in the church have really gone down well with them.
\end{abstract}

Keywords: Deduako-Kodiekrom Community, Methodist Church, giving, appeal for funds

\section{INTRODUCTION}

\section{Religion:}

The key to arriving at an acceptable definition of religion lies in recognizing that religion is a concept which is at once teleological, normative, and orienting, that is, which also explains its enormous importance. It is teleological in that it aims at practice, or a way of life. It is normative, in that it is concerned with providing standards of both morality, or right and wrong, and teleology, or right purpose. It is orienting, in that religions offer an account of the nature of human beings, the universe, and the relationship between the two.

[www. wordnet.princeton.edu/perl/webwn]

We would define religion, then, in this way: religion is a body of doctrine that specify a way of life centered on the maximization of the good, where the good includes both morality and right purposes. Religion therefore provides the sanctions that society cannot fully supply of itself, its moral and legal norms which could be kept in being as a body by secular sanctions. [www.progressiveliving.org/

definition_of_religion_defined.htm]

The religious composition of Ghana in the first postindependent population census of 1960 was 41 percent Christian, 38 percent traditionalist, 12 percent Muslim, and the rest (about 9 percent) of no religious affiliation. The percentage of the general population considered to be Christian rose sharply to 62 percent according to a 1985 estimate.

[www.wikipedia.org/Christianity_in_Africa.htm]

\section{Christianity in Africa:}

Christianity is a monotheistic system of beliefs and practices based on the Old Testament and the teachings of Jesus as embodied in the New Testament and emphasizing the role of Jesus as savior. Christians regards the Bible, a collection of canonical books in two parts, that is, the Old Testament and the New Testament, as authoritative [African Christian Rising].

It is believed by Christians to have been written by human authors under the inspiration of the Holy Spirit, and therefore for many it is held to be the inerrant word of God. 
The books that are considered canon in the Bible vary depending upon the denomination using or defining it. These variations are a reflection of the range of traditions and councils that have convened on the subject.

The Bible always includes books of the Jewish scriptures, and reorganizes them into two parts: the 39 books of the Old Testament containing books originally written primarily in Hebrew and the 27 books of the New Testament containing books originally written primarily in Greek.

Christianity is now one of the two most widely practiced religions in Africa. There has been tremendous growth of Christians in Africa - coupled by a relative decline in adherence to traditional African religions. Much of the Christian growth in Africa is now due to African evangelism rather than European missionaries.

History of the Methodist Church: The Methodist branch of the protestant religion traces its roots back to 1739 where it developed in England as a result of the teachings of John Wesley. While studying at Oxford, Wesley, his brother Charles, and several other students formed a group devoted to study, prayer and helping the underprivileged. They were labeled "Methodist" by their fellow students because of the way they used "rule" and "method" to go about their religious affairs.

The beginning of Methodism as a popular movement began in 1738, when both of the Wesley brothers, influenced by contact with the Moravians, undertook evangelistic preaching with an emphasis on conversion and holiness. Though both Wesley brothers were ordained ministers of the Church of England, they were barred from speaking in most of its pulpits because of their evangelistic methods. They preached in homes, farm houses, barns, open fields and wherever they found an audience.

The introduction of Methodism was the second most serious attempt at evangelizing the natives of Gold Coast, the first one being the efforts of the Basel Evangelical Society. The Roman Catholic had made an unsuccessful attempt earlier while the Bremen effort began sometime after the Methodists had began work in earnest.

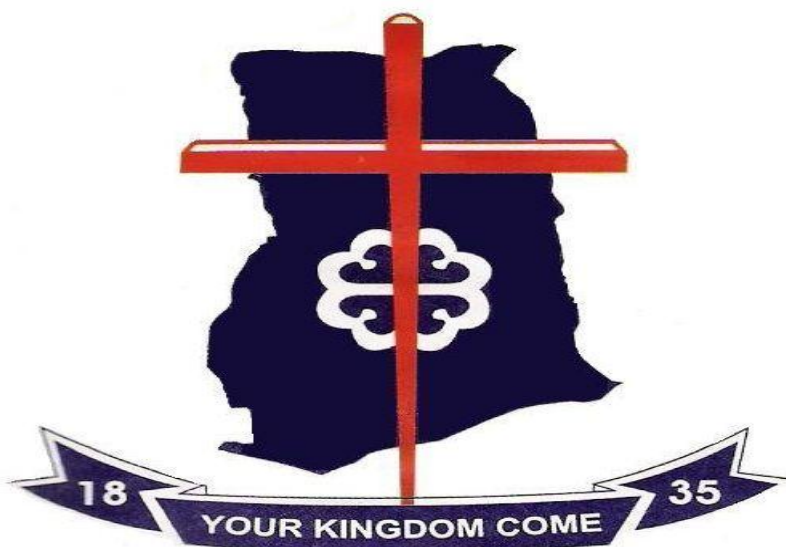

Logo of the Methodist Church [http://en.wikipedia.org/wiki/Methodist_Church_Ghan a]

The Methodist Church is one of the largest and oldest Protestant denominations in Ghana and has always been an indigenous church.

[http://christianity.about.com/od/methodistdenominati on/a/methodisthistory.htm]

Objective of the study: The objective of the study is to analyze Giving amongst the members of the Methodist Church Ghana, Deduako Society. The analysis will be based on data obtained from the church representing the total amounts received during the last five "Appeal for Funds" held by the Church.

\section{MATERIALS AND METHODS}

The analysis was based on data obtained from the church being the amounts given by members of the church in the last five Appeal-for-Funds held by the Church. The members were used as the main points of contact and the trend pertaining to their manner of giving as the records indicated were used. The people are really generous in terms of giving to the Church in the Community.

\section{The Deduako-Kodiekrom Community:}

Deduako-Kodiekrom: The Kumasi metropolis alone accounts for nearly one-third of the region's population. In the Kumasi township, different sects of Christianity, Islam and adherents of African Traditional Religion often vie for greater levels of influence among the populace albeit overtly or through more orthodox means like Evangelism, Crusades, Festivals.

Deduako-Kodiekrom is a community in the Ashanti Region of Ghana. It is found in the central part of the 
country and is well endowed. The DeduakoKodiekrom community is close to Apeadu, Apemso and Kotei. The community is $3.3 \mathrm{~km}$ from Kotei and $4.1 \mathrm{~km}$ from Ayeduase all in the Ashanti Region. The vast territory the community occupies is most densely populated. The population count of the inhabitants of the Deduako community is about $5000+$ people.

Education in the Community: Public education is generally regarded as a distributive policy benefiting the entire community. Obtaining quality education remains a challenge for students in Ghana's rural areas, where government schools lack the most basic amenities. Although government schools in urban areas tend to have more resources, they, too, suffer from a lack of funding.

Private schools routinely prove to offer superior educational opportunities, thanks to families' ability to pay for tuition and special programmes. Ghana's President has pledged in both his state of the nation and Independence Day addresses to improve education for the youth, and, therefore, the future of Ghana.

The community possesses a number of schools. Two government schools, i.e., Preparatory schools and three private schools are found in the Deduako community.

Culture: Culture is the integrated pattern of human knowledge, beliefs, social forms and behavior that depends upon man's capacity for learning and transmitting knowledge to succeeding generations. The mental acceptance of and conviction in the truth, actuality, or validity of something. It is also something believed or accepted as true, especially a particular tenet or a body of tenets accepted by a group of persons.

[Source: http://www.afrikaworld.net/atrcom.html]

The people of Deduako are hospitable, respectable and peace-loving. One could tell from their greeting forms and their general behaviour. The people have wide and generous smiles when you greet them. Traditionally, children are taught in their homes to respect their elders. A child who fails to observe social values is considered as untrained and uncultured. Any visitor to the community is sure to be well received when they happen to visit.

In the Deduako community, a visitor is first given a seat, and then water to drink before he is greeted officially and asked the purpose of his visit. The smile on their faces seem to be permanently in place and it is observed that they are patient as people, kind not only to visitors but to themselves too.

In the community, every child is a treasured element of the society irrespective of how he/she was conceived. Once the child has been born, he/she is an accepted member of the community and the people will do all it takes to see that the child grows in happiness. People take care of each other's properties and their children as well.

Core cultural values and attitudes include hard work, personal and family self-reliance and self-sufficiency, friendliness, and local control of civic affairs. The value of personal individualism is subordinated to the family and the farming enterprise.

The main language of the inhabitants is Akan Twi. Though English is the official language of the country, Akan in its various dialects enjoys a wide usage throughout the community.

Generally, the people of Deduako are very industrious, their innate desires to live independent lives categorizes them as "Hardworking People." They are extremely ambitious and determined to succeed in every venture they undertake.

Religion is very important in the life of the inhabitants of the community. Virtue in African traditional religion is often connected with the communal aspect of life. Examples include such social behaviors as respect for parents and elders, appropriate raising of children, provision of hospitality, and being honest, trustworthy and courageous.

Impact of Christianity on the community: In various aspects of Ghanaian development, nation building have all been impacted upon due to the role Christianity plays. From education to health, there are visible structures and services that the Christian community of Ghana offers not only to Christians alone but to all irrespective of religion.

The Church has contributed to the success of the Deduako community by encouraging virtue and also provides direct and indirect economic and social benefits to the community.

The church has provided valuable contributions to the community in the areas of direct economic contributions, social services and community volunteering, education and civic skills training, and reduced levels of deviance.

These benefits have positively improved the community in direct and indirect manners, and they enhance the stability and the long-term health of the 
community. Overall, it is clear that the church has brought positive benefits to the community.

-Exposition on Giving: Giving is a verb used to indicate that somebody presents or delivers something that he or she owns to another person to keep or use. Giving back to others is one of the easiest ways one can contribute to society [Source: Encarta Dictionaries] .

No matter what everybody's opinion is the Lord looks at our giving very seriously. As one man said: You can give without loving but you can't love without giving. Christians are stewards of God, who has entrusted them with property to use for the furtherance of his kingdom and glory. They cannot escape this responsibility, nor can they delegate it to others.

The first thing the Christian must do is to realize that his property is his. It does not belong to any church, seminary, or religious organization. This is an axiom of giving: One cannot legally or morally give away that which one does not own. Giving is the voluntary transfer of a property title by one party to another, without receiving title to other property in return. (That is why government charity is a contradiction in terms: Government forces taxpayers to fund the welfare programmes. There is no voluntary transfer of property titles.) If one receives title to property in return, one has traded; one has not donated. (If one takes property from the person who possesses title to it without his consent, one is stealing.)

God sees every act done and the motive of every heart in which that gift is bestowed. God loves a cheerful giver. The motive of the heart touches faith. We know that Jesus sees our love and kindness to another in need. Giving as one giving to God that is faith. We know that he will also meet any of our needs in a time of lack because we did not withhold from others.

We do not give out of obligation. We are not debtors to the law. We are free to give because God is a giver. Giving is sowing seeds. We sow bounteously we expect to reap bounteously. We expect something to come from our planting. Sower of seeds also believes in the crop which will come at harvest time [Biblical Principle of Giving: Dr Frutchtenbaum, A.].

The Impact of the Community on Giving in the Church.

Analysis of Giving in the Church: In the Methodist Church, it is considered an honour to 'give' as an expression of worship. It is important to give so that the church can continue to move forward in all areas of ministry and service.

Giving allows us to make a great impact on our community and the Kingdom of God. It is important to give because it is commanded of us in God's word and it also honours Him.

For this analysis, we consider the five most recent appeal-for-funds held in the Church. The tables and their corresponding graphs below summarize the outcome for the appeals based on data obtained from the Church 


\section{APPEAL 1}

\begin{tabular}{|c|c|}
\hline AMOUNT (GHC) & $\begin{array}{l}\text { NUMBER OF } \\
\text { GIVERS }\end{array}$ \\
\hline 50 & 8 \\
\hline 30 & 14 \\
\hline 20 & 19 \\
\hline 10 & 23 \\
\hline 5 & 29 \\
\hline 2 and Below & 41 \\
\hline
\end{tabular}

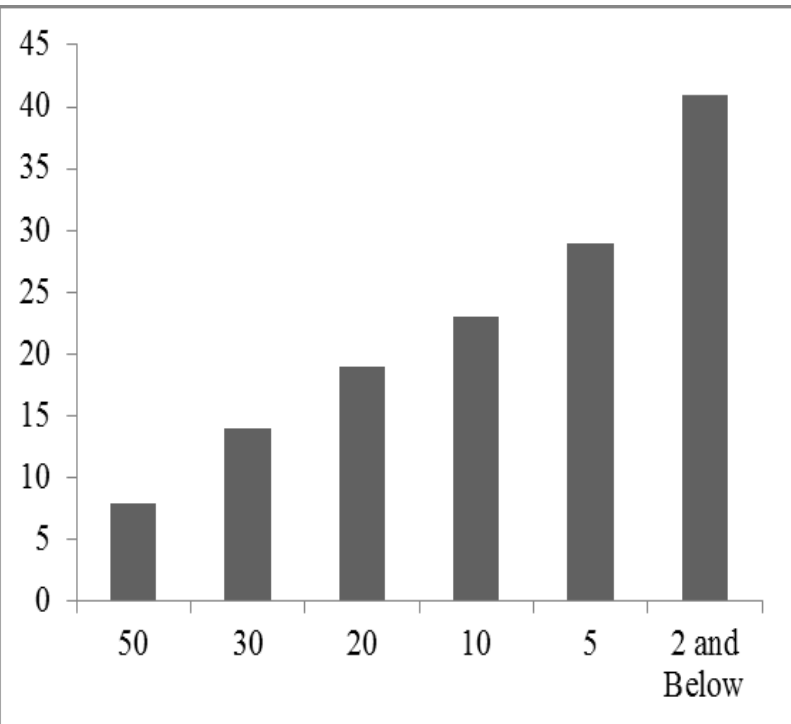

\section{APPEAL 2}

\begin{tabular}{|c|c|}
\hline AMOUNT (GHC) & NUMBER OF GIVERS \\
\hline 50 & 4 \\
\hline 30 & 11 \\
\hline 20 & 13 \\
\hline 10 & 20 \\
\hline 5 and Below & 51 \\
\hline
\end{tabular}




Am. J. Sci. Ind. Res., 2012, 3(5): 292-299

\section{APPEAL 3}

\begin{tabular}{|c|c|}
\hline AMOUNT (GHC) & NUMBER OF GIVERS \\
\hline 50 & 3 \\
\hline 30 & 7 \\
\hline 20 & 9 \\
\hline 10 & 14 \\
\hline 5 & 22 \\
\hline 2 and Below & 31 \\
\hline
\end{tabular}

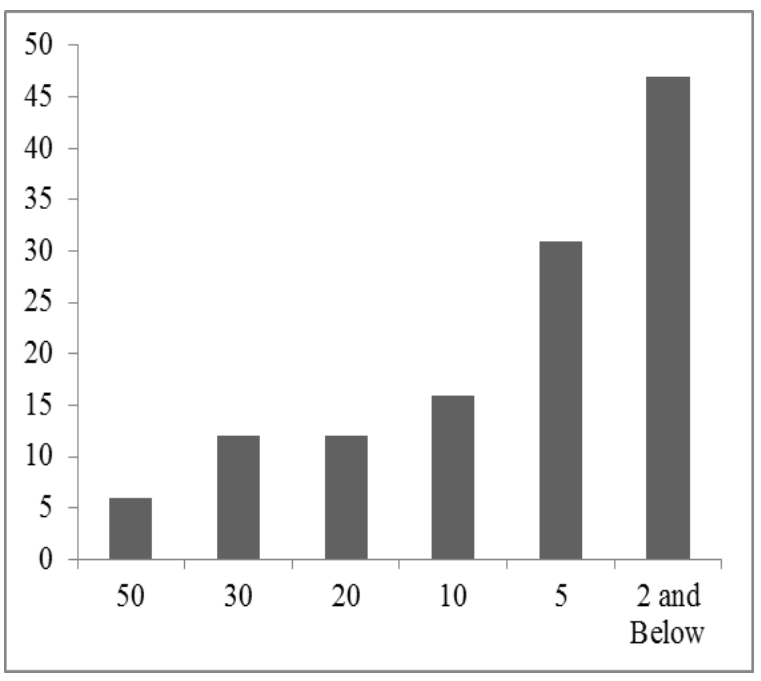

\section{APPEAL 4}

\begin{tabular}{|c|c|}
\hline AMOUNT (GHC) & NUMBER OF GIVERS \\
\hline 50 & 5 \\
\hline 30 & 6 \\
\hline 20 & 10 \\
\hline 10 & 21 \\
\hline 5 & 37 \\
\hline 2 and Below & 59 \\
\hline
\end{tabular}

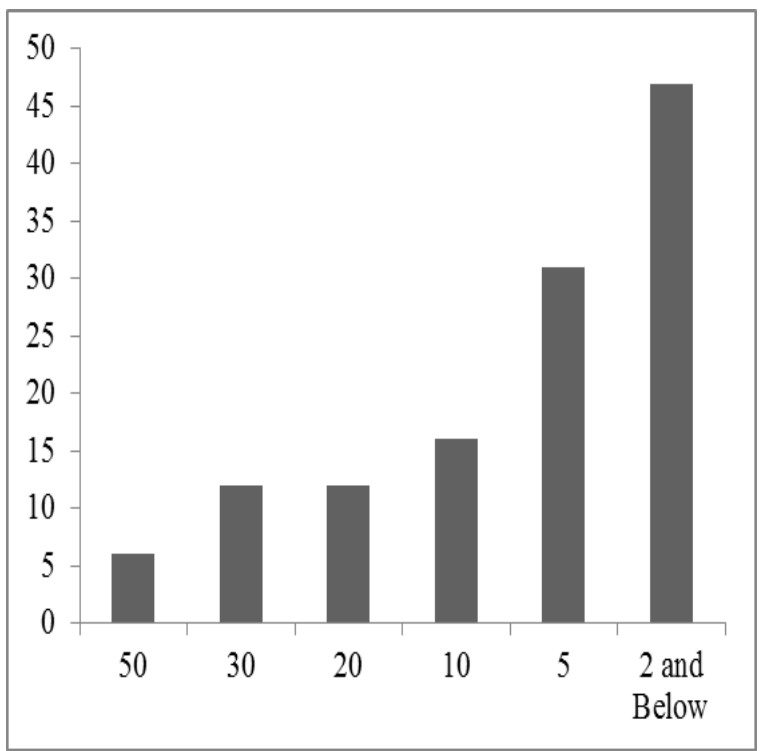




\section{APPEAL 5}

\begin{tabular}{|c|c|}
\hline AMOUNT (GHC) & NUMBER OF GIVERS \\
\hline 100 & 2 \\
\hline 50 & 6 \\
\hline 30 & 12 \\
\hline 20 & 12 \\
\hline 10 & 16 \\
\hline 5 & 31 \\
\hline 2 and Below & 47 \\
\hline
\end{tabular}

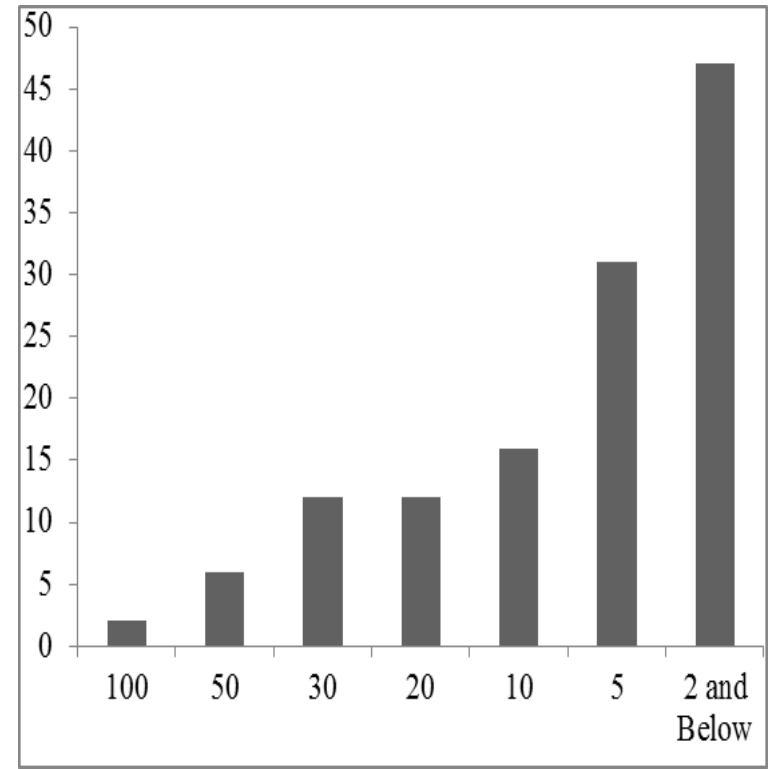

\section{RESULTS AND DISCUSSION}

From the bar graphs above, we notice that the number of givers increases as the amount is reduced. This suggests that all of the people are willing to give but not all of them are able to meet some amounts.

\begin{tabular}{|c|c|c|c|}
\hline APPEAL & $\begin{array}{c}\text { NUMBER } \\
\text { PRESENT } \\
\text { (APPROX.) }\end{array}$ & $\begin{array}{c}\text { AMOUNT OBTAINED } \\
\text { APPROX. (GHC) }\end{array}$ & $\begin{array}{c}\text { AVERAGE AMOUNT } \\
\text { PER PERSON. (GHC) }\end{array}$ \\
\hline APPEAL 1 & 145 & 1300 & 9.00 \\
\hline APPEAL 2 & 105 & 1100 & 8.20 \\
\hline APPEAL 3 & 100 & 820 & 7.10 \\
\hline APPEAL 4 & 150 & 1060 & 10.80 \\
\hline APPEAL 5 & 130 & 1400 & \\
\hline
\end{tabular}

The principles of giving stated above all require one key element: a relationship with God. In the end, obedience in giving comes down to our relationship with the Father. Christians need to be willing to give whatever the Lord may ask, whether it be one percent, five percent, ten percent, twenty percent, or one hundred percent.
The table below summarizes the total number of people present and the total amounts obtained for each of the five appeals.

The average amount given by each individual present was obtained by dividing the total amount realized by the total number of people present. 
helping yourself become stronger. When you give back to the church, all you are really doing is showing your appreciation for what the Lord has done for you. This even includes giving back to people whom you have had no direct dealings with.

When you look at it from this perspective, you will soon understand the real importance of giving to the church. It is your way of showing how grateful you are.

So when you are giving to the church, you are indirectly showing how grateful, which in turn will instill upon you a more powerful sense of positive thinking, which is essential to your reaching your goals and staying at the top.

\section{CONCLUSION}

From the five bar graphs representing the data collected, the following observations were made:

1. The number of participants in these events is relatively large. There is a high level of patronage in the Appeal-for-funds event.

2. The average amount per person ranges between 7.10 and $10.80 \mathrm{GHC}$.

3. The people are very willing when it comes to giving. This is obvious from the trends observed above.

4. The number of givers increases, in almost all the data analyzed, as the asking amount is decreased.

5. In all five datasets, it is observed that the final asking amount receives the highest frequencies. This is certainly due to the fact that the amount most of the children in the church can contribute falls within this category.

6. The amount received depends on the season (time)

The people of the Deduako community are really generous in terms of giving to the Church in the Community. This could also suggest that the countless educational programmes on the importance of giving held in the church have really gone down well with them.

It is also clearly obvious from the figures above that they take Giving to the Lord and to the church seriously.
Compared to the amount of money the people in the church made in the month, they are still able to give generously. In spite of the fact that most of the people do not make a lot of money monthly, the people contribute massively to the church. Through their giving, the community has aided in the building up and development of the Methodist Church in the community and its maintenance.

\section{REFERENCES}

1. Arnold, J. L.: Biblical Giving

2. Charles Pinkey: A Spiritual Basis Regarding Giving.

3. Fruchtenbaum, A. The Biblical Principle of Giving, 2005.

4. Gehman R. J. "African Traditional Religion in Biblical Perspective", p.50, 1989.

5. Gyekye, K. "An Essay on African Philosophical Thought. The Akan Conceptual Scheme, revised edition, Philadelphia; Temple University Press", 1995.

6. http://christianity.about.com/od/methodistdenomina tion/a/methodisthistory.htm

7. http://Christianity.about.com/od/whatdoesthebibles ay/i/churchgiving.htm

8. http://en.wikipedia.org/wiki/Christianity_in_Ghana/

9. http://en.wikipedia.org/wiki/Methodist Church Gha na

10. http://globalpressinstitute.org/globalnews/africa/ghana/ghana-aims-improve-publicrural-schools-2011\#ixzz1 nm6ltrg7

11. http://library.generousgiving.org/page.asp?sec\%3D 9\%26page\%3D172

12. http://www .wordnet.princeton.edu/perl/webwn

13. http://www.afrikaworld.net/afrel/sarpong.html

14. http://www.afrikaworld.net/atrcom.html

15. http://www.apostolic.edu/biblestudy/files/giving.htm

16. http://www.progressiveliving.org/ definition_of_religion_defined.htm

17. http://www.trinityfoundation.org/journal.php?id=99

18. http:/www.wikipedia.org/Christianity_in_Africa.htm

19. Ikenga-Metuh, E. God And Man In African Religion London; Geoffrey Chapman, 1981.

20. Martin, R. Biblical Basis of Giving- Part 1

21. Reconstructing a Biblical Model for Giving: A Discussion of Relevant Systematic Issues and New Testament Principles; Andreas J. Kostenberger and David A. Croteau, Southeastern Baptist Theological Seminary

22. "RELIGION" Microsoft Encarta 2009 [DVD]. Redmond, WA: Microsoft Corporation, 2008

23. The Laws of Biblical Prosperity: Make a Way Ministries, Cornerstone Financial Counselors.

24. www.Ashanti.com.au

25. www.Hope-wilbanks.hubpages.com/hub/theimportance-of-giving-back/

26. www.library.yale.edu/ 